\title{
KAJIAN AL-QURAN DAN HADITS TENTANG KESEHATAN JASMANI DAN RUHANI
}

\author{
Mia Fitriah Elkarimah \\ Universitas Indraprasta PGRI Jakarta \\ Email: el.karimah@gmail.com
}

\begin{abstract}
On some verses of the Qur'an and the hadith of the Prophet, which will be described in this paper, there is a correlation that Islam places great emphasis on cleanliness. On the one hand, God instructed to preserve the health and physical hygiene, on the other hand, God also commands for maintaining mental health and mental. Cleanliness became the base of health and wellness is a way to move. This paper will only be focusing on peeling the Islamic concept of physical and mental health in the study of the Koran and Hadith, starting from health in Islamic terminology, the scope of health, such as the concept of personal hygiene and environmental sanitation, ban food and drink unclean and not good, balanced lifestyle, preventive to achieve optimal levels of health status.
\end{abstract}

\begin{abstract}
Abstrak
Dari beberapa ayat al-Qur'an dan hadits Nabi, yang akan diuraikan pada tulisan ini, terdapat korelasi bahwa Islam sangat menekankan tentang kebersihan. Di satu sisi Allah memerintahkan untuk menjaga kesehatan dan kebersihan fisik, di sisi yang lain Allah juga memerintahkan untuk menjaga kesehatan mental dan jiwa. Kebersihan menjadi pangkal dari kesehatan dan kesehatan merupakan jalan untuk beraktivitas. Tulisan ini hanya akan menfokuskan diri pada mengupas konsep Islam tentang kesehatan jasmani dan rohani dalam Kajian al-Quran dan Hadits, dimulai dari kesehatan dalam terminologi Islam, ruang lingkup kesehatan, seperti konsep tentang kebersihan diri dan sanitasi lingkungan, larangan makanan dan minuman yang haram dan tidak baik, pola hidup yang seimbang, preventif untuk mencapai tingkat derajat kesehatan yang optimal.
\end{abstract}

Key words : kebersihan, kesehatan, ruang lingkup kesehatan, kajian alQuran dan Hadits 


\section{Pendahuluan}

Al-Qur'an diturunkan Allah SWT kepada Nabi Muhammad saw kurang lebih abad ke-6 masehi, yang secara gambang banyak sekali tertulis tentang makanan dan kesehatan. Tetapi orang mulai berbicara masalah gizi dan kesehatan itu di awal abad 19, ditambah diakuinya ilmu gizi dalam salah satu cabang ilmu kesehatan pada tahun 1926 ketika May Swartz Rise dikukuhkan sebagai profesor ilmu gizi pertama di Universitas Columbia, New York Amerika Serikat. ${ }^{1}$ Dalam literatur keagamaan, bahkan dalam hadist-hadist Nabi, ditemukan sekian banyak perintah untuk menjaga makanan dan kesehatan dari mulai perintah menutup hidangan, mencuci tangan sebelum makan, larangan bernafas sambil minum, tidak kencing atau buang air di tempat yang tidak mengalir atau di bawah pohon, adalah contohcontoh praktis dari sekian banyak tuntunan Islam dalam konteks menjaga kesehatan.

Dari salah satu alasan inilah Islam sering disebut sebagai agama yang sangat proporsional. Islam datang sebagai agama untuk kepentingan duniawi dan ukhrawi secara menyeluruh. Tidak terbatas jalur hubungan antara hamba dengan Tuhannya (horisontal) saja, tetapi Islam juga mengatur hubungan secara vertikal. Hubungan horisontal dan vertikal tersebut terikat oleh dua sumber utama; alQur'an dan Sunnah sebagaimana firman Allah swt.

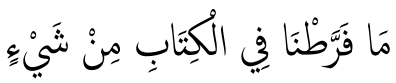

"Tidak ada sesuatu pun yang Kami luputkan di dalam Kitab" (Q.S. AlAn'am/6: 38)

Dari ayat ini tersirat bahwa kaum muslim dituntut untuk menyelesaikan masalah-masalah kontemporer secara relevan, realistis dan rahmatan lil alamin yang semua prinsipnya ada dalam Al-Qur'an dan Sunnah, baik yang terperinci maupun yang global. ${ }^{2}$

${ }^{1}$ Emma Pandi Wirakusumah, M.Sc., Sehat Cara Alqur'an \& Hadis, Jakarta, Mizan Publika, 2010), x.

${ }^{2} \mathrm{Al}-\mathrm{Qurthubi}$ menulis dalam tafsirnya, "Tidak ada satu persoalan pun dalam agama kecuali kami berikan petunjuknya dalam Al-Qur'an yang bersifat eksplisit maupun implisit tetapi mendapatkan kejelasan dari RasulullahShallahu 'Alaihi Wasallam.” Lihat al-Jami' li ahkamil Qur'an 6/420.

106 |TAJDID vol. XV, No. 1, Januari - Juni 2016 
Islam menetapkan tujuan pokok kehadirannya untuk memelihara agama, jiwa, akal, harta dan keturunan. Setidaknya tiga dari yang disebut di atas berkaitan dengan kesehatan, yaitu jiwa, akal dan keturunan. ${ }^{3}$. Tidak heran jika ditemukan bahwa Islam sangat kaya dengan tuntutan kesehatan, baik kesehatan jasmani dan rohani. Dalam konteks kesehatan jasmani saja, Nabi pernah menegur beberapa sahabatnya yang bermaksud melampaui batas beribadah, jkarena kebutuhan jasmaninya terabaikan, yang secara otomatis kesehatannya tergangu.

Rasulullah bersabda:

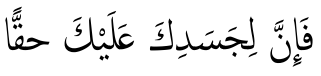

"Sesunggubnya badanmu mempunyai hak atas dirimu" (HR. al-Bukhari). ${ }^{4}$

Manusia diciptakan di dunia ini untuk menjadi khalifah dan beribadah kepada Allah. Namun, kedua fungsi tersebut tidak akan bisa terlaksana dengan baik tanpa adanya kesehatan yang dimiliki oleh setiap manusia. Melihat pentingnya kesehatan tersebut, Islam memiliki perspektif tersendiri tentang kesehatan.

\section{Definisi Kesehatan}

Dalam bahasa Arab kata sehat diungkapkan dengan kata ashshihhah atau yang seakar dengannya yaitu keadaan baik, bebas dari penyakit dan kekurangan serta dalam keadaan normal. ${ }^{5}$

\footnotetext{
${ }^{3}$ Quraish Shihab, Wawasan al-Quran (Bandung: Mizan Pustaka, 2007), 181.

${ }^{4}$ Bukhari Juz 5 hal 1995 No. Hadis 4903.

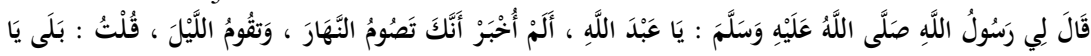

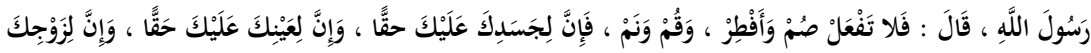
عَلَيْكَ حَقُّا

Dari 'Abdullah bin 'Amr bin al-'Ash dia berkata bahwa Rasulullah saw. telah bertanya (kepadaku, "Benarkah kamu selalu berpuasa di siang hari dan dan selalu berjaga di malam hari?" Aku pun menjawab, "Ya (benar), ya, Rasulullah." Rasulullah saw. pun lalu bersabda, "Jangan kau lakukan semua itu. Berpuasalah dan berbukalah, berjagalah dan tidurlah! Sesungguhnya badanmu mempunyai hak atas dirimu, matamu mempunyai hak atas dirimu, dan isterimu pun mempunyai hak atas dirimu." (Hadis Riwayat al-Bukhari dari 'Abdullah bin 'Amr bin al-'Ash)

${ }^{5}$ Ahmad Ibn Faris Ibn Zakariya, Abi al-Husayn, Maqayis Al-Lughah, Juz IV, (Mesir: Musthafa Al-Babi Al-Habibi, 1970), 219.
}

TAJDID vol. XV, No. 1, Januari - Juni 2016 |107 
Rasulullah sering menggunakan kata ini dalam sabdanya:

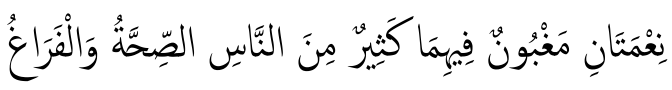

"Banyak manusia merugi karena dua nikmat; kesehatan dan waktu luang" (HR. al-Bukhari dari Ibnu Abbas).

Sehat seperti dinyatakan WHO adalah: a state of complete physical, mental and social wellbeing, not merely the absence of disease or infirmity, atau dikatakan sebagai kondisi yang sempurna baik secara fisik, mental dan sosial dan tidak sekedar bebas dari penyakit dan kelemahan. Oleh sebab itu, secara lebih operasional kesehatan dirumuskan oleh M.K Tadjudin sebagai keadaan atau kualitas organisme manusia yang mampu menjalankan fungsinya (dengan baik), karena faktor genetika dan lingkungan (2008 : 6). Dengan demikian, kesehatan adalah totalitas yang menunjukkan tidak adanya penyakit, dan bahwa organorgan tubuh berfungsi secara normal. Konsep kesehatan secara holistik meliputi berbagai dimensi fisik, mental, sosial, ekonomi, pendidikan, makanan dan minuman (nutrisi), kuratif dan preventif yang secara keseluruhan merupakan bagian dari cakupan materi kesehatan masyarakat. ${ }^{6}$

Menurut Quraish Shihab istilah al-Sbibhab selalu digandengkan dengan al-'Afiyah. Padahal masing-masing digunakan untuk makna yang berbeda, kendati diakui tidak jarang hanya disebut salah satunya (secara berdiri sendiri), karena masing-masing kata tersebut dapat mewakili makna yang dikandung oleh kata yang tidak disebut, dengan dalil karena wa yang berarti "dan" adalah kata penghubung yang sekaligus menunjukkan adanya perbedaan antara yang disebut pertama (ash-shibhah) dan yang disebut kedua (al-'afiyah). Atas dasar itu, dapat dipahami bahwa ada perbedaan makna di antara keduanya. Dalam literatur keagamaan, bahkan dalam hadis-hadis Nabi ditemukan sekian banyak doa, yang mengandung permohonan al'Afiyah, di samping permohonan memperoleh sehat. Dalam kamus bahasa Arab, kata ini diartikan sebagai perlindungan Allah untuk hamba-Nya dari segala macam bencana dan tipu daya. Perlindungan itu tentunya tidak dapat diperoleh secara sempurna kecuali bagi mereka yang mengindahkan petunjuk-petunjuk-Nya. Maka kata al-

${ }^{6}$ M.K Tadjudin, Concept of Health and Desease, (Jakarta: faculty of Medecine and Health Science Syarif Hidayatullah state Islamic University, 2008), 15

108 | TAJDID Vol. XV, No. 1, Januari - Juni 2016 
'Afiyah dapat diartikan sebagai berfungsinya anggota tubuh manusia sesuai dengan tujuan penciptaannya. ${ }^{7}$

Senada dengan pandangan yang dikemukakan Zulkifli Yunus bahwa kata al-shihhah merujuk pada fungsi, sedangkan kata al-'afiyah merujuk kepada kesesuaian dengan maksud penciptaan. Mata yang sehat adalah mata yang dapat digunakan untuk melihat tanpa alat bantu, sedangkan mata yang 'afiat adalah mata yang tidak bisa digunakan untuk melihat sesuatu yang dilarang melihatnya, karena maksud Tuhan menciptakan mata adalah sebagai penunjuk pada kebenaran, membedakannya dari yang salah. ${ }^{8}$

Kesehatan tidak akan terealisir tanpa adanya kebersihan, atau yang diistilahkan dengan taharah. ${ }^{9}$ Dari sini terlihat bahwa hubungan kebersihan dengan kesehatan tidaklah bersifat parsial, tetapi bersifat fungsional dan saling melengkapi. Antara keduanya ada hubungan kausalitas. Sehat bisa dikatakan jika diri, tempat dan lingkungan kita bersih, dengan kebersihan yang kita tunjukkan itu secara langsung kita tunjukkan bahwa kita sehat. Kebersihan atau taharah adalah bagian dari proses pembersihan diri dan satu-satunya jalan utama (syarat) agar seseorang bisa melaksanakan ibadah yang diterima Allah. Dengan melaksakan taharah yang benar sesuai prinsip-prinsip yang diajarkan dalam sumber Islam, maka ia akan menjadi faktor kunci dalam mendapatkan kekhusukan shalat dan ibadah lainnya. Di sinilah pentingnya taharah untuk diperhatikan oleh setiap pribadi muslim.

Dalam Islam, taharah tidak hanya diartikan kebersihan lahiriah semata, melainkan kebersihan batin. ${ }^{10}$ Selain istilah taharah untuk mununjukkan arti kebersihan, juga ada nazafah yang sering disebutkan Rasullulah dalan sabdanya.

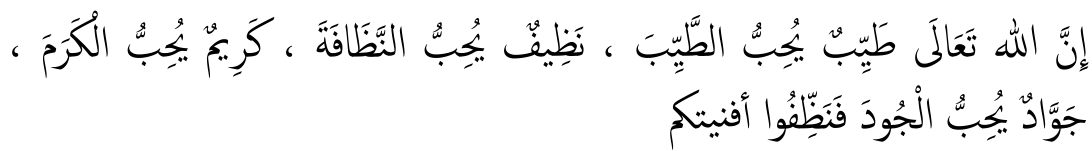

${ }^{7}$ Quraish Shihab, Wawasan al-Quran (Bandung: Mizan Pustaka, 2007), 181-182.

${ }^{8}$ Zulkifli Yunus, Kesehatan Menurut Islam, (Bandung: Pustaka, 1994), 57

${ }^{9}$ Dalam Al-Qur'an dan hadis terdapat tiga macam kosa kata yang digunakan berkaitan dengan kebersihan, yaitu thaharab, tazkiyyah dan nazafah. Penekanan masing-masing kata akan tampak dalam siyaqul kalam, sehingga ada kalanya sama atau berbeda satu sama lain. Lihat. Kesehatan Perspektif Al-Qur'an, oleh lajnah pentashihan mushaf Al-Qur'an, 2009 : 21.

${ }^{10}$ az-Zuhaili, Tafsir al-Munir, (Beirut: Darul Fikr, tth), 219.

TAJDID Vol. XV, No. 1, Januari - Juni 2016 | 109 
"Sesunggubnya Allah baik dan menyukai kebaikan, bersib dan menyukai kebersiban, mulia menyukai kemuliaan, murah hati dan senang kepada kemuraban hati, maka bersibkanlah halaman kalian" (HR. Tirmidri dari Abu burairah). ${ }^{11}$

Ungkapan lain tentang kebersihan yang digunakan dalam AlQur'an ternyata ada yang dilihat dari aspek kebersihan harta dan jiwa dengan menggunakan istilah tazkiyah. Misalnya ungkapan Allah dalam al-Qur'an ketika menyebutkan zakat seakar dengan tarkiyah, yang bermaksud untuk membersihkan harta, sehingga harta yang dizakati itu bersih. Bersih dan kotornya harta sebenarnya ada korelasi dengan jiwa.

\section{Urgensi Kesehatan dalam al-Qur'an dan Hadis}

Ajaran Islam menekankan kepada umatnya betapa penting arti kesehatan dalam hidup. Tuntutan ajaran Islam amat kaya dengan kesehatan. Dengan kesehatan akan melahirkan berbagai aktifitas untuk menjaga dan memelihara kebersihan dan mencegah terjadinya penyakit. Dalam konteks ini, terlihat betapa urgennya memelihara kesehatan dalam Islam. Allah SWT berfirman :

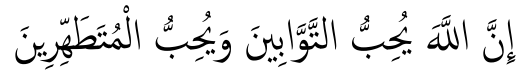

"Sesunggubnya Allah menyukai orang-orang yang bertaubat dan menyukai orang-orang yang mensucikan diri."(Q.S. al-Baqarah/2 : 222).

Dalam ayat ini terdeskripsi betapa sifat manusia yang sangat dicintai Allah adalah orang yang memelihara kesehatan dengan menjaga kebersihan. Kebersihan dalam ayat ini beriringan dengan taubat. Taubat sangat inheren dengan kesehatan rohani khususnya mental, sedangkan kesehatan lahiriah menghasilkan kesehatan jasmani.

Kesehatan tentu saja bukan satu-satunya hikmah di balik perintah melakukan kebersihan, tetapi sebagaimana dikatakan alSunandaji dalam Mawabib al-Badi' fi Hikmatus Tasyri ada hikmah lainnya yang tersembunyi di balik tirai-tirai redaksioanalnya kenapa ada perintah dan larangan. Setidaknya, hikmah kesehatan inilah yang

${ }^{11}$ Dijelaskan kualitas hadist ini

قال أبو عيسى هذا حديث غريب و خالد بن إلياس يضعف.قال الشيخ الألباني : ضعيف

110 |TAJDID vol. XV, No. 1, Januari - Juni 2016 
disingkap oleh banyak pakar kesehatan. ${ }^{12}$ Bisa dibuktikan dengan fenomena ramainya buku tentang manfaat shalat, wudhu, shaum ditinjau dari berbagai segi seperti kesehatan atau psikologis dan lain sebagainya. ${ }^{13}$

Ketika Abu Malik al-Asy'ari meriwayatkan sebuah hadis Rasulullah, beliau bersabda:

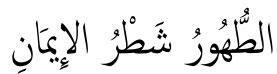

\section{"Kebersiban sebagian dari iman" (HR. Muslim)14}

Hadis ini menurut Abu Zakariya an-Nawawi dalam Syarah Muslim, merupakan salah satu dasar Islam yang menunjukkan posisi taharah dalam Islam. Begitu pentingnya sehingga Islam menempatkannya sebagian dari iman. Makna "sebagian dari iman" dalam pandangan mayoritas ulama adalah bahwa pahala bersuci berlipat hingga mencapai sebagian pahala beriman. Dengan kata lain, orang yang tidak dapat menjaga kebersihan, berarti keimanannya masih belum sempurna. Kebersihan bagi umat Islam sangat penting diterapkan. Untuk mewujudkan kebersihan dan keindahan itu, dapat dimulai dari diri kita sendiri, di lingkungan keluarga, masyarakat, maupun di lingkungan kerja atau sekolah. Islam menghendaki umatnya melakukan kebersihan menyeluruh. Dengan demikian, akan terwujud kehidupan manusia, individu, dan masyarakat yang selamat, sehat, bahagia, dan sejahtera lahir dan batin.

Alasan mengapa kesehatan menjadi hal yang sangat penting diperhatikan adalah karena kalau orang sehat berarti ia kuat. Lemah dan kuatnya seseorang dalam melakukan suatu ibadah tergantung pada kesehatannya. Orang yang memiliki kesehatan yang baik akan memiliki kekuatan yang lebih dari orang yang sakit. Sedangkan orang

${ }^{12}$ Abdul qodir bin muhammad Sa'iid al-Sunandaji, Mawabib Al-Badi' fi Hikmatus Tasyri', (t.tt: Kurdistan al-Ilmiyah, 1997), 20

${ }^{13}$ Adnan Tharsyah, Keajaiban Shalat Bagi Kesehatan, Meraih Manfaat Shalat Secara Medis, Klinis, \& Psikologis (Jakarta: Senayan Abadi: 2008)

${ }^{14}$ Hadist selengkapnya di muslim, bab fadhlu al-wudhu, juz 1, 140.

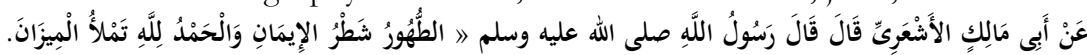

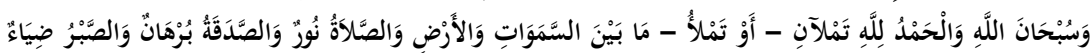

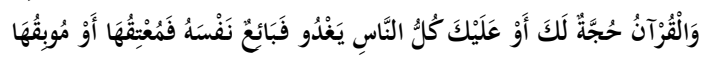


kuat itu lebih disukai di sisi Allah daripada orang yang lemah, sebagaimana sabda Rasulullah:

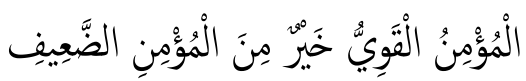

"Seorang mukmin yang kuat lebih baik dan lebih disayangi Allah daripada mukmin yang lemab" (HR. Muslim). ${ }^{15}$

Dan tidak kalah pentingnya lagi, Islam menempatkan persoalan kebersihan sebagai bagian dari Islam ${ }^{16}$ dan fitrah manusia ${ }^{17}$. Dengan kata lain, salah satu kecenderungan manusia adalah cinta kepada kebersihan.

\section{Ruang Lingkup Kesehatan Menurut al-Qur'an dan Hadis}

Tingginya perhatian Islam terhadap kesehatan, terutama fisik, dapat dilihat dari banyaknya karya-karya ulama klasik yang terispirasi oleh petunjuk al-Qur'an tentang kesehatan, seperti Manafi' al-Agziyat Wa Madarruha yang ditulis oleh Abu Bakar ar-Razi. Selain itu, Ibnu an-Nafis, ulama Damaskus pada tahun $1220 \mathrm{M}$ menulis dalam

\footnotetext{
${ }^{15}$ Matan lengkapnya adalah

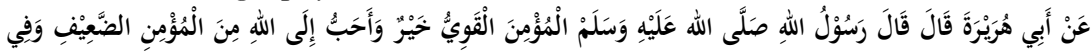

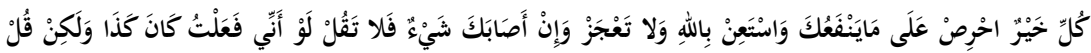

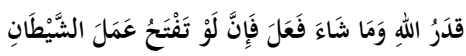

Dari Abi Hurairah berkata, Rasulallah SAW. Bersabda: mukmin yang kuat lebih baik dan lebih disayangi oleh Allah dari mukmin yang lemah dan masingmasing ada keutamaannya; berhati-hatilah kamu untuk kemanfaatan dirimu dan mintalah pertolongan Allah dan jangan berputus asa. Dana kalau kamu dapat cobaan maka janganlah berkata kalau aku terbuat tentulah begini atau begitu, tetapi katakanlah ini hanya takdir dari Allah dan berbuat apa yang dikehendakinya, karena kalimat "kalau" pembuka pintu bagi syaitan"

16Riwayat dari abu Hurairah lihat Ali ibn Abd-al-Malik al-Hindi, Kanz al'Ummāl fī sunan al-aqwāl wa'l af'āl, bab fadhl thaharah juz 9/277

تنظفوا بكل ما استطعتم، فإن الله تعالى بنى الإسلام على النظافة، ولن يدخل الجنة إلا كل نظيف

"bersihkanlah segala semampu kamu, sesungguhnya Allah Ta'ala membangun Islam itu atas dasar kebersihan dan tidak akan masuk surga kecuali setiap yang bersih"

${ }^{17}$ Shahih al-Bukhari juz 5/2209

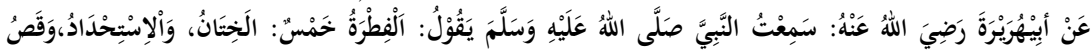

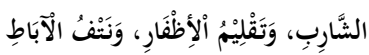

"Lima perkara dari fitrah, yaitu khitana, mencukur bulu kemaluan, kumis, ,memotong kuku dan mencabuti bulu ketiak" 
bukunya asy-Syamil tentang pentingnya gizi untuk proses penyembuhan. Ulama lain yang menulis tema yang sama adalah Hunain bin Ishaq, Muhammad bin Zakaria ar-Razi, Ibnu Zahr dan asSamarqandi, serta Ibnu Khladun, bapak sosiologi. Buku-buku yang ditulis ulama Islam banyak diterjemahkan ke dalam bahasa asing, misal Geovani De cavua menerjemahkan kitab al-Agziyah karya Musa Bin Maimun, Natman menerjemahkan al-Qanun Ibnu Sina, dan sebagainya. Demikian kontribusi Islam bagi kemajuan peradaban umat manusia. ${ }^{18}$ Perintah dan tuntunan untuk hidup sehat dalam alQur'an dan sunnah itu sangatlah banyak yang pada intinya mengarahkan manusia ke arah kebaikan, baik jasmani maupun rohani. Di antara kebersihan jasmani adalah: kebersihan diri dan lingkungan.

Kebersihan atau taharah dalam kaitannya dengan ibadah mendapat porsi yang cukup panjang dan tema yang selalu diusung pertama kali dalam pembahasan fiqh. Biasanya taharah menurut syariat Islam ialah suatu kegiatan bersuci dari hadas kecil dan besar, sehingga seorang diperbolehkan untuk mengerjakan suatu ibadah dengan tuntutan harus dalam keadaan suci. Kegiatan bersuci dari hadas dapat dilakukan dengan cara berwudhu, mandi dan tayammum, sebagaimana yang dijelaskan dalam firman Allah:

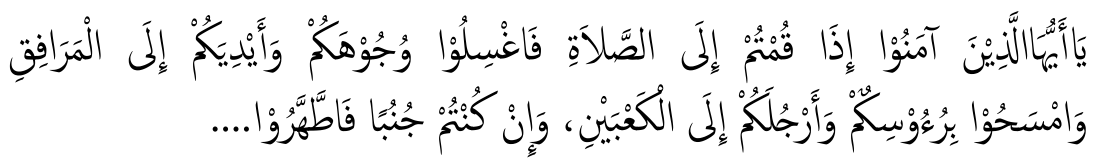

"Wabai orang-orang yang beriman. Bila kamu hendak melaksanakan salat, maka basublah wajabmu dan tanganmu sampai siku, dan sapulah kepalamu, dan (basub) kedua kakimu sampai mata kaki. Jika kamu junub maka bersibkanlah (dengan mandi)"(QS. Al-Ma'idah $5: 6$ ).

Allah memerintahkan shalat dan mengharuskan orang yang akan mengerjakannya untuk membersihkan badan dengan cara berwudhu, dan ini berkaitan erat dengan kebersihan dan kesucian lahiriah dan maknawiyah. Karena itu, Allah menjadikan kesucian yang sempurna menjadi salah satu syarat sahnya shalat, sebagaimana sabda Nabi Muhammad saw.

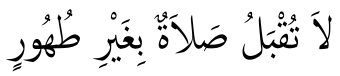

${ }^{18}$ Tim Tafsir Tematik Litbang Depag, 306

TAJDID vol. XV, No. 1, Januari - Juni 2016 |113 


\section{"Allah tidak menerima shalat seseorang tanpa kesucian" (HR. Muslim).19}

Beberapa hasil penelitian menunjukan bahwa wudhu memiliki dampak kesehatan bagi tubuh sebagaimana dikemukakan Oleh Abdullah Bin Abd al-Aziz dalam al-I'jaz Fi Al-Qur'an Wa as-Sunnah (2008),20 sehingga kita sebagai seorang muslim sangat dianjurkan untuk selalu mengambil air wudhu, bukan hanya pada waktu sholat, tetapi juga di waktu yang lain. Salah satunya ketika hendak membaca Al-Qur'an, setelah mengantarkan jenazah, bangun dari tidur ataupun ketika sedang mengantuk. Selain fungsi fisiologis, wudhu juga efektif mengendalikan emosi. Setiap kali merasa ingin marah, seorang muslim sangat dianjurkan untuk mengambil air wudhu untuk mendinginkan pikiran dan menentramkan hati.

Manfaat kesehatan dapat ditemukan pula dalam kewajiban mandi bagi wanita yang berhenti haid, ${ }^{21}$ nifas atau setelah hubungan suami istri22 dan sebagainya. Al-Qur'an juga mengisyaratkan perintah membersihkan pakaian seperti dalam surah al-Mudassir $74: 4$. Pakaian adalah sesuatu yang melekat dengan tubuh sehingga kebersihannya sangat diperlukan bagi kesehatan tubuh, sebagaimana terhadap kebersihan badan dan pakaian.

Sanitasi lingkungan merupakan juga unsur mendasar dalam menjaga kesehatan. Yang dimaksud sanitasi lingkungan adalah menciptakan lingkungan yang sehat yang bebas dari penyakit. Seperti kebersihan tempat tinggal, tempat umum, tempat ibadah dan lain-

${ }^{19}$ Shahih Muslim, bab wajib thaharah lishalat, juz 1, hal. 140 , no hadis 557 Diikuti setelahnya

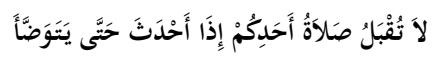

"Tidak diterima shalat seseorang jika ia berhadas sehingga ia berwudhu"

${ }^{20}$ Abdullah Bin Abd al-Aziz dan 'abd al-jawwad as-sawi al-I'jaz. Fi Al-Qur'an Wa as-Sunnah. (Jeddah : Darul Jiyad Li Al-Nasyr Wa Al-Tauzi, 2008)

${ }^{21}$ Beberapa dalil Al-Qur'an dan hadist

$$
\text { وَلَا تَقْرَبُوهُنَ حَتَّى يَطْهُرْنَ }
$$

"Dan janganlah kamu mendekati mereka, sebelum mereka suci....(QS. AlBaqarah/2: 222)

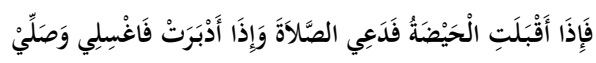

"Jika telah tiba masa haidhmu maka tinggalkan shalat, dan bila selesai masa haidmu maka mandilah kemudian shalatlah." (HR. Bukhari)

22 "Dan jika kalian dalam keadaan junub, maka mandilah." (QS. Al-Ma'idah 5: 6)

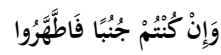

114 |TAJDID vol. XV, No. 1, Januari - Juni 2016 
lain. Isyarat tentang kebersihan tempat diperlihatkan pada firman Allah SWT:

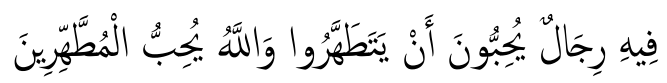

"Dalamnya ada orang-orang yang ingin membersibkan diri. Allah menyukai orang-orang yang bersib" (at-Taubah 9: 108).

Ada beberapa hal yang perlu kita perhatikan berkaitan dengan kebersihan lingkungan. Pertama, menjaga kebersihan sumber air, seperti sumur, kolam, sungai, dan lain-lain, karena air itu akan kita gunakan sebagai sumber air minum, mencuci, mandi dan sebagainya. Air yang tercemar akan menyebabkan lahirnya berbagai penyakit Rasulullah saw. bersabda:

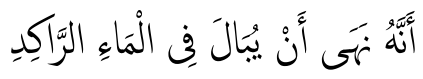

"Rasulullah melarang kencing dalam air yang tergenang" (HR. Muslim dari Jabir).

Di sini tersirat makna lebih luas bahwa kita dilarang untuk mengotori air itu dengan cara apapun, bukan hanya sebatas kencing saja. Kedua, menjaga kebersihan tempat yang ramai dikunjungi, karena jika saja tempat itu kotor dan menjadi sarang penyakit. Menyadari bahaya tersebut Rasulullah dengan tegas melarang kita untuk buang air besar dan kecil di tempat yang dilewati banyak orang. Rasulullah saw. bersabda:

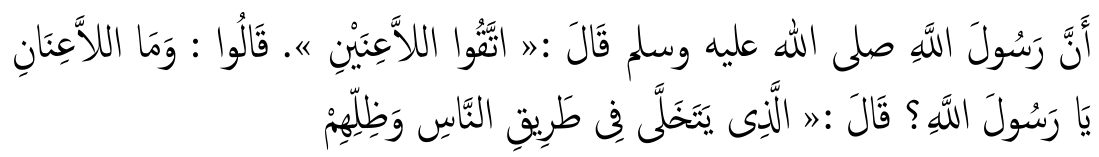

Rasulullah bersabda: "takutilah menjadi orang yang dilaknat orang lain, sababat bertanya: siapa orang yang menjadi laknat orang lain?. Rasulullab menjawab: yaitu orang yang buang hajat di tempat yang dilalui orang lain, atau tempat berteduh orang lain" (HR. Muslim)

Ketiga, kita juga dilarang meludah di sembarangan tempat, karena di samping ludah itu sendiri sangat menjijikan, juga menjadi salah satu sarana menularnya beberapa penyakit. Dalam hal ini Rasulullah saw. bersabda:

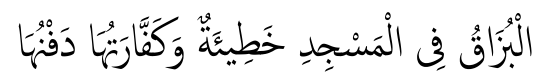

TAJDID vol. XV, No. 1, Januari - Juni 2016|115 
Meludah di mesjid adalah dosa, dan kafarat (taubat) nya adalah dengan menanam ludah itu. (HR. Bukbari dari Anas bin Malik).

Dalam hadis ini dapat kita ambil hikmah bahwa Islam melarang kita untuk meludah di tempat-tempat umum seperti mesjid dan juga tempat lainnya, karena sama-sama menjijikkan dan menjadi salah satu faktor tertularnya penyakit.

\section{Makanan dan Minuman}

Orang sering tidak sadar dengan hal-hal yang perlu diperhatikan terkait makanan dan minuman ini. Banyak sekali orang yang tidak memiliki spiritual awareness. Umumnya mereka menganggap makan dan minum adalah urusan dunia ansich yang tidak ada kaitannya dengan agama. Ada juga yang tidak peduli dengan sesuatu yang dimakannya, baik dari sisi zatnya maupun dari sisi cara memperolehnya. Padahal, dalam urusan makan dan minum ini, Islam menaruh perhatian yang cukup serius. Dalam surah Quraisy ayat 3-4 diterangkan bahwa Allah menjadikan kecukupan kebutuhan pangan sebagai salah satu sebab utama kenyamanan dalam beribadah. Di samping itu, makanan dan minuman yang dikonsumsi akan secara langsung mempengaruhi tubuh, baik secara fisik maupun psikis.

Imam al-Ghazali mengumpamakan urusan makanan dalam agama ibarat fondasi pada sebuah bangunan. Menurutnya, jika fondasi itu kuat dan kokoh, maka bangunan itu pun akan berdiri tegak dan kokoh. Demikian sebaliknya, apabila pondasi itu lemah dan rapuh, niscaya bangunan itu pun akan ambruk dan runtuh. Al-Ghazali lalu mengutip sebuah hadis yang diriwayatkan Imam Thabrani, "Perbaikilah makananmu, niscaya Allah akan mengabulkan doamu."23 Salah satu cara yang diajarkan oleh Islam untuk meraih kesehatan adalah dengan mengatur pola makan yang baik. Ajaran Islam dalam mengelola makan itu ada beberapa hal, di antaranya: pertama, mengonsumsi makanan yang halal dan baik.

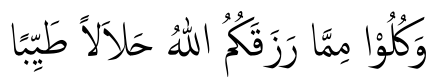

"Dan makanlah dari yang diberikan Allah kepadamu sebagai rezeki yang balal dan baik". (QS. Al-Ma'idah 5; 8).

${ }^{23}$ Nur wahyuni, Study Analisis Sertifikasi Halal Dan Keamanan Pangan (studi analisis SK 07/DIR/LPPOM MUI/V13 tentang daftar makanan kritis), AKS AKK Yogyakarta, Social Akademika Vol 1, No. 1 Juni 2013

116 |TAJDID Vol. XV, No. 1, Januari - Juni 2016 
Ketika berbicara tentang makanan yang dikonsumsi, al-Qur'an selalu menekankan salah satu dari dua sifat yaitu halal dan thayyib. Kata halal apabila al-Qur'an dan hadis menjelaskannya dan tidak melarangannya. Namun makanan yang halal yang dijelaskan semua dalam 2 sumber hukum Islam tidak seluruh makanan ada, sehinggga ulama berijtihad pada Prinsip segala sesuatu yang diciptakan Allah itu mubah, kecuali ada dalil yang shahih dan sharih yang mengharamkan. ${ }^{24}$

Kata thayyib dalam ayat al-Qur'an di atas adalah yang baik, dalam arti yang memiliki manfaat bagi tubuh, tidak sekedar halal. Sebab, ternyata saat ini pun terdapat makanan halal, akan tetapi tidak bagus atau tidak memberi manfaat untuk kesehatan. Kualitas makanan yang balalan thayibban yang dipesankan al-Qur'an itu mengharuskan kaum muslim memahami ilmu gizi dan menjaga kualitas makanan yang thayyiban dengan cara yang tepat.

Ini dibuktikan juga dimana Allah menyebutkan sejumlah buahbuahan dengan berbagai rasa dan namanya dalam al-Qur'an, yang oleh ilmu pengetahuan modern ditegaskan memiliki khasiat vitamin dan dapat mencegah beberapa jenis penyakit. ${ }^{25}$

Kedua, tidak berlebihan dalam makan dan minum.

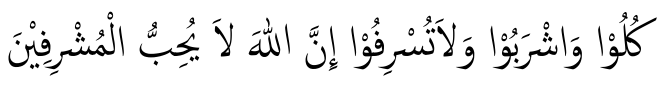

"Makan dan minumlah, tetapi jangan berlebih-lebihan. Sesunggubnya Allah tidak menyukai orangyang berlebih-lebiban”.'QS. Al-A raf 7 : 31).

Rasulullah saw. pernah menyuruh Abbas untuk berdoa memohon kesehatan, "Wahai Abbas, mohonlah kepada Allah SW'T untuk kesehatanmu di dunia ini dan di akhirat nanti." (HR. Tirmidzi).

\footnotetext{
${ }^{24}$ Yusuf Qardhawi, Halal Haram Dalam Islam (Solo, Era Intermedia, 2003), 36.

25"Dan Dialah yang menurunkan air hujan dari langit, lalu Kami tumbuhkan dengan air itu segala macam tumbuh-tumbuhan, maka Kami keluarkan dari tumbuhan-tumbuhan itu tanaman yang menghijau. Kami keluarkan dari tanaman yang menghijau itu butir yang banyak; dan dari mayang kurma mengurai tangkai-tangkai yang menjulai, dan kebun-kebun anggur, dan Kami keluarkan pula zaitun dan delima yang serupa dan yang tidak serupa. Perhatikanlah buahnya di waktu pohonnya berbuah, dan (perhatikan pula) kematangannya. Sesungguhnya, pada yang demikian itu ada tanda-tanda (kekuasaan Allah) bagi orang-orang yang beriman." (al-An'aam $6: 99$ )
}

TAJDID Vol. XV, No. 1, Januari - Juni 2016 |117 
Salah satu anjuran Rasulullah saw. untuk menjaga kesehatan di antaranya adalah dengan menjaga perut dari hal-hal yang menimbulkan penyakit.

Hadis Nabi shallalahu 'alaihi wasallam yang menyebut tentang penyakit yang berpuncak dari perut kini dibuktikan dengan penemuan sains. Diriwayatkan bahwa Rasulullah bersabda:

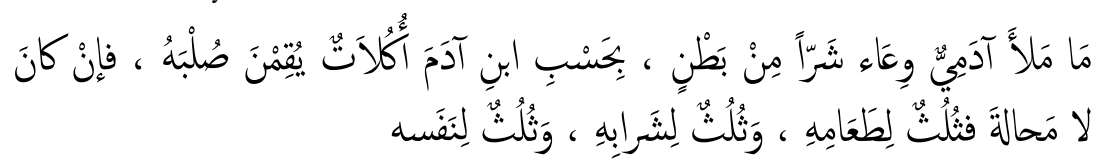

"Tidak ada bejana yang lebih buruk yang diisi oleh manusia melainkan perutnya sendiri. Cukuplah seseorang itu mengonsumsi beberapa kerat makanan yang dapat menegakkan tulang punggungnya. Jika terpaksa, maka ia bisa mengisi sepertiga perutnya dengan makanan, sepertiga lagi dengan minuman, dan sepertiga sisanya untuk nafas." (HR. Tirmidri).26

Ketiga, tidak memakan makanan yang diharamkan.

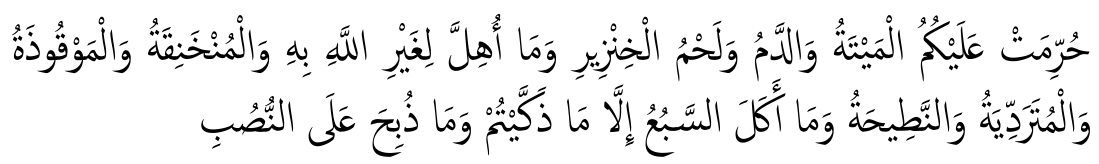

'Dibaramkan bagimu (makan) bangkai, darah, daging babi, dan (daging) bewan yang disembelih bukan atas (nama) Allah, bewan yang tercekik, yang dipukul, yang jatub, yang ditanduk, dan yang diterkam binatang buas, kecuali yang sempat kamu sembelib". (QS. Al-Ma'idah 5 : 3).

Bagi seorang muslim makan dan makanan bukan sekedar penghilang lapar saja atau sekedar terasa enak dilidah, tapi lebih jauh dari itu harus mampu menjadikan tubuhnya sehat, baik jasmani maupun rohani sehingga mampu menjalankan fungsinya sebagai "khalifah fil Ardhi". Rasulullah saw. pernah berkata dalam suatu hadisnya, "Seorang hamba Allah tidak akan berpindah dua kakipun pada hari kiamat, sampai ia mampu menjawab empat hal: umurnya bagaimana dihabiskan, pengetahuan bagaimana diamalkan, hartanya bagaimana dinafkahkan serta tubuhnya bagaimana digunakan atau diboroskan" (HR.Tirmidzi).

\footnotetext{
${ }^{26}$ Lihat sunan Tirmidzi, bab Karahah Katsratul Akl, juz 4, hal 590, no hadis
} 2380

118 | TAJDID Vol. XV, No. 1, Januari - Juni 2016 
Setiap makanan yang dilarang di dalam Al-Qur'an ternyata saat ini memiliki argumentasi ilmiah yang dapat dibuktikan dengan ilmu pengetahuan. Makanan yang diharamkan dapat mengganggu kesehatan manusia, baik pengaruh buruk bagi kesehatan maupun mengandung berbagai penyakit yang membahayakan tubuh. Ditegaskan oleh Quraish Shihab bahwa sebagian pakar, baik agamawan maupun ilmuwan, berpendapat bahwa jenis makanan dapat mempengaruhi mental manusia. Al-Harali (w. $1232 \mathrm{M}$ ) menyimpulkan hal tersebut setelah membaca firman Allah yang mengharamkan makanan dan minuman tertentu karena makanan dan minuman tersebut rijs. Kata rijs diartikan sebagai keburukan budi pekerti atau kebobrokan mental. Kenyataan ini menunjukkan bahwa kuantitas dan kualitas makanan berpengaruh terhadap perasaan manusia. 27

Menurut Rasyid Rida, Allah mengharamkan bangkai hewan yang matinya tidak disembelih baik matinya karena tertabrak, terjatuh, tercekik, karena tua, atau karena suatu penyakit. disebabkan pada bangkai darahnya tidak keluar, darah yang membeku di dalam tubuh hewan tersebut kemudian menjadi sarang tempat berkumpulnya mikroba yang berbahaya bagi tubuh manusia..28Sebenarnya tanpa ada pengharaman dari nashal- Qur'an atau hadis pun, manusia dengan akal dan hatinya akan mengharamkan bangkai dengan sendirinya dikarenakan menjijikan dan membahayakan. Dan banyak lagi hikmah ilmiyah yang menyatakan bahwa pelarangan dalam Islam bukan tanpa alasan.

\section{Pola Hidup yang seimbang}

\section{Tidur Sarana Istirahat}

Allah telah menciptakan pergantian malam dan siang, bukan sesuatu yang tak bermakna. Pergantian ini dimaksudkan adalah untuk memberikan kesempatan kepada manusia untuk berusaha pada siang hari dan beristirahat pada malam hari setelah lelah berusaha. Hal ini kembali membuktikan bahwa Islam sangat memperhatikan masalah kesehatan. Dalil yang menjelaskan tentang hal ini adalah:

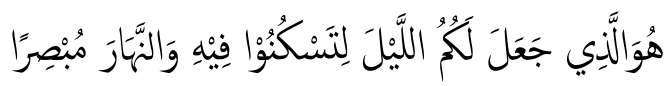

${ }^{27}$ Quraish Shihab, Wawasan al-Quran, 184-185.

${ }^{28}$ Rasyid Rida, Tafsir al-Manar, (Mesir: Maktabah al-Qahirah, tth), 7.

TAJDID Vol. XV, No. 1, Januari - Juni 2016 |119 
"Dialah yang menjadikan malam bagimu agar kamu beristirahat padanya dan menjadikan siang terang benderang". (QS. Yunus/10: 67).

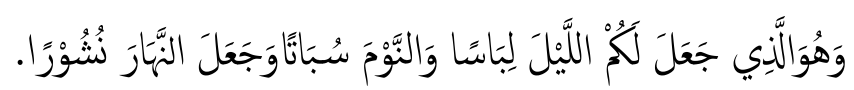

"Dan Dialah yang menjadikan malam untukmu (sebagai) pakaian, dan tidur untuk istirahat, dan Dia menjadikan siang untuk bangkit berusaha". (QS. Al-Furqan/25:47).

Menurut Ahmad Syauqi al-Fanjari, setiap manusia membutuhkan waktu istirahat dengan tidur sekitar 8 jam setiap hari. Jika kurang dari itu berarti tidurnya tidak berkualitas, dan akibatnya akan mengganggu kerja otak. Dalam keadaan terbangun otak bekerja dengan aktif dan otot, jantung serta saraf menegang. Akibat aktivitas tersebut zat-zat beracun menumpuk dalam tubuh. Cara menghilangkannya adalah dengan tidur yang dapat menghentikan aktivitas kerja otak. Dan tidur di malam hari lebih berkualitas dari pada tidur di siang hari. ${ }^{29}$ Salah satu bentuk perhatian Islam juga terhadap tubuh agar diistirahatkan adalah berlakunya ketentuan rukhsah atau keringanan dalam menjalankan beberapa ketentuan agama

\section{Menggerakkan Tubuh}

Tidak ditemukan ayat dalam al-Qur'an yang secara tegas menjelaskan urgensi olahraga bagi kesehatan tubuh, namun isyarat itu ditemukan dalam firman Allah surah al-Anfal $8: 60$

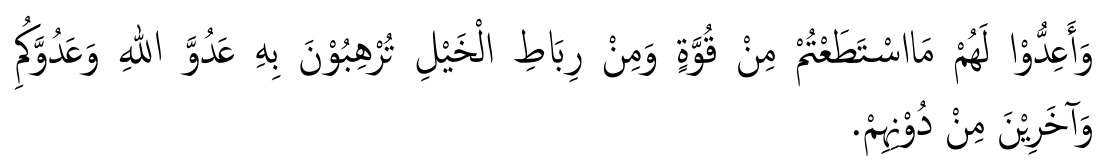

'Dan persiapkanlah dengan segala kemampuan untuk menghadapi mereka dengan kekuatan yang kamu miliki dan dari pasukan berkuda yang dapat menggentarkan musub Allah, musubmu dan orang-orang selain mereka". (QS. Al-Anfal/8; 60).

Imam al-Baihaqi meriwayatkan dari Abu Rafi' bahwa Rasulullah bersabda, "Di antara hak yang harus dipenuhi orang tua adalah mengajarkan menulis, renang dan memanah"30 . Ketiga hal tersebut

${ }^{29}$ Ahmad Syauqi al-Fanjari, Al-Qurān Wath Thibbul Hadìts (Kairo: AlHayyiah al-Mishriyyah al-Ammah lil-Kitāb, 2000), 58.

${ }^{30}$ Lihat di Syu'bul Iman, imam al-Baihaqi, juz 6, hala 401, no hadis 8665

120 |TAJDID vol. XV, No. 1, Januari - Juni 2016 
sebagai contoh pentingnya mengajarkan ilmu pengetahuan dan melatih fisik agar anak tumbuh sehat dan kuat. Rasulullah juga mendoakan keberkahan bagi umatnya yang selalu cepat bangun pagi untuk beraktivitas. ${ }^{31}$ Dan dulu pada masa Nabi Muhammad saw tiada seorang tertinggal dari shalat berjama'ah, kecuali orang-orang munafik yang terang kemunafikannya. ${ }^{32}$ "Sebagaimana beliau selalu berdoa agar terhindar dari sikap lemah dan malas. ${ }^{33}$

\section{Berupaya Melakukan Pencegahan dan Penyembuhan}

Menurut Quraish Shihab pembicaraan literatur keagamaan tentang kesehatan fisik dimulai dengan meletakkan prinsip "pencegahan lebih baik daripada pengobatan". Karena itu dalam konteks kesehatan ditemukan sekian banyak petunjuk Kitab Suci dan Sunah Nabi saw. yang pada dasarnya mengarah pada upaya pencegahan yaitu membiasakan pola hidup sehat. ${ }^{34}$ Konsep pencegahan penyakit bisa dilihat dari penjelasan hadis Rasulullah yang berkaiatan bahwa beliau tidaklah makan sebelum lapar dan berhenti sebelum kenyang. Apabila pola makan Rasul tersebut dapat diterapkan oleh manusia, maka tidak akan terjadi penyakit-penyakit

نعم حق الولد على الوالد أن يعلمه الكتابة و السباحة والرمي وأن يؤديه طيبا

${ }^{31}$ Hadis Abu Daud, juz 24, hal 177, no hadis 15443

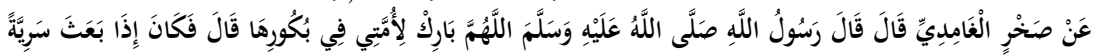

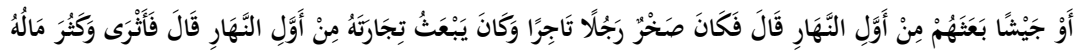

Nabi shollallahu 'alaih wa sallam berdoa: "Ya Allah, berkahilah ummatku di pagi hari." Rasulullahshollallabu 'alaih wa sallam biasa mengirim sariyyah atau pasukan perang di awal pagi dan Sakhru merupakan seorang pedagang, ia biasa mengantar kafilah dagangnya di awal pagi sehingga ia sejahtera dan hartanya bertambah."

Melalui doa Rasulullah shollallahu 'alaib wa sallam. Ia menginginkan umatnya menjadi kumpulan manusia yang gemar beraktifitas di awal waktu. Dan hanya mereka yang sungguh-sungguh mengharapkan keberhasilan dan keberkahan-lah yang bakal sanggup berpagi-pagi dalam kesibukan beraktifitas

${ }^{32}$ Lihat di Sunan Al-Kubra Lil Baihaqi, juz 3, hal 58, no hadis 5150

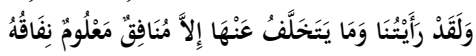

${ }^{33}$ Lihat shahih al-Bukhari, bab at-ta'awudz min ardzail umur, juz 5, hal 2343, no hadis 6010

$$
\begin{aligned}
& \text { كان رسول الله صلى الله عليه و سلم يتعوذ يقول ( اللهم إني أعوذ بك من الكسل وأعوذ بك من الجبن وأعوذ بك }
\end{aligned}
$$

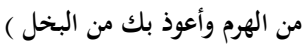

TAJDID Vol. XV, No. 1, Januari - Juni 2016|121 
yang banyak terjadi pada manusia masa kini yang berlebih-lebihan dalam hal makan dan minum. seperti diabetesmelitus.

Islam menjelaskan berbagai cara pencegahan penyakit menular, juga mencegah penyebarannya. Di antaranya adalah dengan karantina penyakit. Nabi Muhammad SAW bersabda: "Jauhkanlah dirimu sejauh satu atau dua tombak dari orang yang berpenyakit lepra". Dan: "Larilah dari penderita lepra sebagaimana kamu lari dari harimau." (HR. Bukhari). Selain upaya pencegahan, upaya penyembuhan sesuatu yng menjadi kewajiban. Dalam al-Qur'an dikisahkan bahwa Nabi Ayyub terkena penyakit fisik yang parah. Allah swt memerintahkan berendam dalam air dan menghentaknya kakinya ke bumi ini salah satu upaya memperoleh cara kesembuhan.

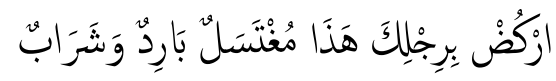

"Hentakkanlah kakimu; inilah air yang sejuk untuk mandi dan untuk minum." (Sad $38: 41-42)$

Penyembuhan dengan air itu diperoleh setelah doa Nabi Ayyub yang terus-menerus dikabulkan oleh Allah Subhana Wata'ala seperti disebut dalam surah al-Anbiya $21: 84$. Upaya penyembuhan yang diajarkan Al-Qur'an selain yang bersifat fisik (usaha lahir) juga melalui doa dan optimisme akan pertolongan Allah Subhana Wata'ala. Ini juga yang dilakukan Nabi Sulaiman setelah diuji dan terkulai lemas di atas kursinya (karena sakit), kemudian dia berdoa dan bertobat, dan senantiasa optimis. ${ }^{35}$

Upaya pencegahan juga bisa dilihat ketika Umar bin Khathab dan sahabat lainnya hendak ke Syam. Di tengah perjalanan mereka bertemu dengan pasukan yang baru pulang dari Syam dan mengabarkan bahwa di Syam sedang dilanda wabah penyakit. Maka Umar memutuskan untuk kembali ke Madinah setelah hasil musyawarah. Tapi Abu Ubaidah menolak dengan mengatakan, "Tidakkah kita lari dari takdir Allah?" Umar menjawab, "Kita lari dari takdir Allab ke takdir Allah yang lain. Bukankah jïa kamu menggembalakan untamu dan melihat dua lembah yang satu subur dan satu lagi

${ }^{35}$ Firman Allah surah Sad 38 : 34-40

122 | TAJDID vol. XV, No. 1, Januari - Juni 2016 
kering, kamu memilih yang subur. Karena masing-masing keputusan adalah takdir.'"36

Sementara itu perintah dan tuntunan untuk kebersihan jasmani sangat dianjurkan. Kebersihan rohani juga tidak kalah penting dalam kehidupan setiap individu. Dengan cara memperbaiki jiwa dalam menjaga dirinya tidak ternodai oleh kotoran - kotoran jiwa seperti riya', takabbur, hasad (dengki), dan penyakit hati lainnya. Jiwa yang sehat disebut dalam al-Qur'an sebagai qalbun salim. Jiwa seperti inilah yang akan selamat di akhirat, seperti firman Allah swt. dalam Q.S. asySyu'ara'/26:88-89. Upaya mewujudkan yang demikian itu ditunjukkan oleh Allah swt. dan rasul-Nya. Caranya adalah dengan senantiasa mengingat Allah, mengerjakan segala perintah-Nya sebagaimana dinyatakan oleh firman Allah swt. yang artinya: "Sesungguhnya dengan mengingat Allah, jiwa akan memperoleh ketenangan" (QS. Al$\mathrm{Ra} d \mathrm{~d} / 13: 28)$.

Sebagaimana yang dikutip Nur Ahmad bahwa Kartino Kartono mengartikan kesehatan jiwa sebagai ilmu tentang jiwa yang mempermasalahkan kehidupan kerohanian yang sehat, yang memandang pribadi manusia sebagai satu totalitas psikofisis yang kompleks. Menurutnya orang yang berpenyakit mental ditandai dengan fenomena ketakutan, pahit hati, apatis, cemburu, iri hati, dengki, eksplosif, ketegangan batin dan sebagainya. Sementara orang yang sehat jiwanya, adalah mempunyai kemampuan untuk bertindak secara efisiensi, memiliki tujuan hidup yang jelas ada koordinasi antara segenap potensi memiliki integrasi kepribadian dan selalu tenang batinnya. ${ }^{37}$

Kebersihan yang bersifat rohani lebih banyak menggunakan kata tazkiyah. Tazkiyah menurut bahasa berarti suci, berkembang dan

${ }^{36}$ Diriwayatkan dari Abbas "Lalu datanglah Abdurrahman bin Auf ra. Dia tidak hadir saat rapat karena beberapa hajatnya. Abdurrahman pun berkata: 'Aku ahu apa yang tengah terjadi. Dan aku pernah mendengar Rasullllah saw bersaba: "Jika engkau mendengar ada wabah di suatu negeri, maka jangan engkau masuki negeri tersebut, dan jika wabah itu terjadi di suatu negeri sementara engkau ada di dalamnya, maka janganlah engkau keluar dari negeri tersebut untuk menghindari dan lari darinya.'Dari sinilah rasul menetapkan orang yang sehat dan yang sakit tidak boleh bercampur, sesuai dengan prinsip kehati-hatian "al had₹r" dan sikap preventif (pencegahan).

${ }^{37}$ Nur Ahmad, "Kerangka Dasar Membangun Kesehatan Spiritual Melalui Pendekatan Psikologi Islam." Jurnal STAIN Kudus, Vol. 6, No. 2, Desember (2015), 279.

TAJDID vol. XV, No. 1, Januari - Juni 2016 |123 


\section{Mia Fitriah Elkarimah}

bertambah. ${ }^{38}$ Sedangkan yang dimaksud disini adalah membersihkan jiwa dari sifat-sifat tercela, membuang seluruh penyakit hati, lalu menghiasi jiwa dengan sifat-sifat terpuji. ${ }^{39}$ Secara ringkas, menyucikan jiwa dan hati disebut dengan istilah tazkiyah nafs yang intinya menyucikan diri dari perbuatan syirik dan derivasinya seperti sombong, dengki dan sifat-sifat tercela lainnya, dan pada saat yang sama melahirkan sifat-sifat positif. ${ }^{40}$

Tahap awal penyucian seseorang dari segala perbuatan jelek ialah dengan cara taubat/istigfar. Lihatlah kehidupan Nabi Shallallahu 'Alaihi Wa Sallam yang setiap waktunya selalu diisi dengan taubat dan istighfar, bahkan sampai akhir hayat hidupnya pun beliau tidak lepas dari amalan tersebut. Padahal beliau adalah orang yang telah diampuni dosa yang telah lalu dan akan datang. Sebagaimana hal ini terdapat pada firman Allah surah al-Fath/48:1-2.41

Ditambahkan pula, tarkizaun nufus merupakan salah satu hajat utama yang diminta Rasulullah saw. Dalam doanya, Rasululah mengatakan:

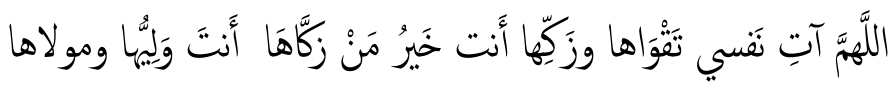

"Ya Allah anugerabkanlah ketakwaan pada jiwaku dan sucikanlah ia, karena Engkaulah sebaik-baik. Drat yang mensucikan dan Engkaulah pemiliknya dan penguasanya." (HR Muslim).42

Dosa dan kemaksiatan diibaratkan oleh Rasulullah Shallallahu 'Alaihi Wa Sallam laksana noda-noda hitam yang akan memudarkan

${ }^{38}$ Ibnu Manzur, Lisan al-Arab, (Mesir : Dar al-Misriyyat, t.t. ), 358

${ }^{39}$ al-Imam Abi Ja'far Muhammad ibn Jarir Al-Tabari, Tafsir Al-Thabari, Beirut: Dar al-Fikr, 1978), 456.

${ }^{40}$ Said Hawa, Tazkiyatun Nafsi Intisari Ibya' (terjemahan). (Jakarta: Pena. Pundi Aksara, 2005), 153.

${ }^{41}$ Ditambahkan pula Dalam kitab shohih, dari Aisyah radhiyallahu 'anha, beliau berkata,

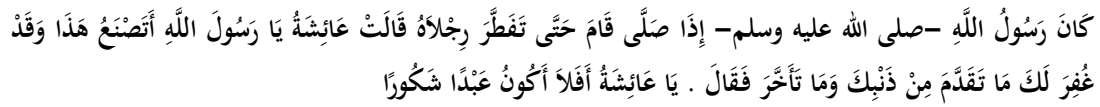

"Rasulullah shallallahu 'alaihi wa sallam terbiasa shalat sehingga kakinya pecah-pecah. Kemudian aku mengatakan kepada beliau, 'Wahai rasulullah, kenapa engkau melakukan hal ini padahal engkau telah diampuni dosa yang telah lalu dan akan datang.' Lalu Rasulullah shallallahu 'alaihi wa sallam mengatakan, 'Tidakkah engkau menyukai aku menjadi hamba yang bersyukur."' (HR. Muslim)

${ }^{42}$.Lihat shahih muslim, kitab az-zikr, bab at-tawuz, no 4899, 13/251 
kalbu seorang mu'min yang jernih. Kalau tidak segera dibersihkan dengan taubat kepada Allah, ia akan memekatkan dan menutup mati mata hati itu sendiri sehingga ia akan keras bagaikan batu, bahkan bisa lebih keras dari itu sebagaimana termaktub dalam surah AlBaqarah/2:74.

\section{Kesimpulan}

Firman Allah dan hadist Nabi yang berkaitan tentang anjurananjuran yang berhubungan dengan menjaga kesehatan, dimulai dari menjaga pola hidup, kebersihan diri dan lingkungan, dan kegiatan fisik juga jelas menunjukkan tauladan islam itu mewajibkan hidup sehat. Rasulullah juga meninggalkan hal-hal yang tidak bermanfaat sesuai perintah al-Qur'an. Beberapa ayat al-Qur'an dan hadist Nabi sebagaimana yang diuraikan di atas mengantarkan Islam haruslah memiliki konsep kesehatan yang prima untuk beramal sholeh secara maksimal yang akan menghantarkannya kepada keberhasilan duniaakherat.

\section{Daftar Pustaka}

Al-Fanjari, Ahmad Syauqi. Nilai Kesehatan dalam Syariat Islam. Jakarta: Bumi Aksara, 2000.

al-Qusyairî, An-Naisâbûrî, Al-Imâm Abî al-Husain Muslim bin alHajjaj. Shabih Muslim bi Syarh An-Nawawi. Beirut: t.p, t.t.

Al-Bukhari, Al-Imam Abu Abdillah Muhammad bin Ismail. Sbabih al-

Bukhari. Beirut Libanon: Dar al-Kutub al-Ilmiyah. 1992.

Ahmad bin Hanbal, Al-Imām. Musnad. Beirut: Dārul-Fikr, t.t.

Ahmad, Nur. "Kerangka Dasar Membangun Kesehatan Spiritual

Melalui Pendekatan Psikologi Islam." Jurnal STAIN Kudus, Vol. 6, No. 2, 2015.

Ahmad Ibn Faris Ibn Zakariya, Abi al-Husayn. Maqayis Al-Lughah, Juz

IV, Mesir: Musthafa Al-Babi Al-Habibi, 1970.

Athab, Muhammad Abdul Qadir, Sunan al-Kubra lil Imam Abi Bakar Ahmad bin al-Husain bin Ali al-Baibaqi, Juz IV, Libanon: Daar alKutub alllmiah. , t.t.

al-Baihaqi, Abu Bakar Ahmad bin Husain. Syu'bu al-Iman. Beirut: Dar al-Kutub al-Ilmiyah, 1990.

al-Sunandaji, Abdul Qodir bin Muhammad Sa'id. Mawahib Al-Badi' fi

Hikmatus Tasyri', Kurdistan al-Ilmiyah, 1997.

az-Zuhaili, Wahbah. Tafsir al-Munir fi al-aqidah wa asySyar ïab wa alManhaj. Damaskus: Darul Fikri. , t.t.

TAJDID Vol. XV, No. 1, Januari - Juni 2016 |125 
At-Thabary, Abu Ja'far Muhammad bin Jarir, Tafsir at-Thabari jami' albayan anta'wil aaii al-Qur'an. Dimasqi: Daar al-Qalam, t.t.

At-Tirmidzi, Muhammad Bin Isa Bin Surah, Sunan at-Tirmidri. Riyadh: Maktabah al-Ma'aarif Linnasyri Wattauzi'., t.t.

Abdullah Bin Abd al-Aziz dan 'Abd al-Jawwad al-Sawi, al-I'jaz Fi AlQur'an Wa as-Sunnah. Jeddah: Darul Jiyad Li Al-Nasyr Wa AlTauzi, 2008.

Hawa, Said. Tazkiyatun nafsi intisari Ibya' (terjemahan). Jakarta: Pena. Pundi Aksara. 2005.

Ibnu Manzur, Ansari. Lisan al-Arab, Mesir: Dar al-Misriyyat, t.t.

Ibn Ahmad, Muhammad Ibn Abi Bakr al-Qurthubi, al-Jami' li Abkam al-Qur'an, Beirut: Mu'assasah al-Risalah, 2006.

Nur Ahmad, "Kerangka Dasar Membangun Kesehatan Spiritual Melalui Pendekatan Psikologi Islam." Jurnal STAIN Kudus, Vol. 6, No. 2, Desember, 2015.

Tafsir Tematik, Kesehatan Dalam Perspektif Al-Qur'an. Jakarta: Depag RI, 2009.

Tharsyah, Adnan. Keajaiban Shalat Bagi Kesehatan, Meraih Manfaat Shalat Secara Medis, Klinis, \& Psikologis. Jakarta: Senayan Abadi, 2008.

Tadjudin, M. K. Concept of Health and Desease. Jakarta: Faculty of Medecine and Health Science Syarif Hidayatullah state Islamic University, 2008.

Qardhawi, Yusuf. Halal Haram dalam Islam. Solo: Era Intermedia, 2003.

Wahyuni, Nur. "Study Analisis Sertifikasi Halal Dan Keamanan Pangan (Studi Analisis SK 07/ DIR/LPPOM MUI/V13 tentang daftar makanan kritis)." AKS AKK Yogyakarta. Social Akademika Vol 1. No. 1 Juni, 2013.

Wirakusumah, Emma Pandi. Sehat Cara Alqur'an \& Hadis. Jakarta: Mizan Publika, 2010. 